\title{
Microbiological Quality and Sensory Aspects of Greek Yoghurt With the Addition of Carambola Jam (Averrhoa carambola)
}

\author{
Mailson Gonçalves Gregório ${ }^{1}$, Alícia Nayana dos Santos Lima de Brito ${ }^{1}$, Nágela Maria Henrique Mascarenhas ${ }^{1}$, \\ Moisés Sesion de Medeiros Neto ${ }^{1}$, Luís Paulo Firmino Romão da Silva ${ }^{1}$, Semirames do Nascimento Silva ${ }^{1}$, \\ Morgana Aragão Araújo ${ }^{1}$, Airton Gonçalves de Oliveira ${ }^{1}$, Roberta de Oliveira Sousa Wanderley ${ }^{1}$, \\ Joana D'arc Paz Matos ${ }^{2}$, Larissa Monique de Sousa Rodrigues ${ }^{1}$, Maria Suiane de Moraes ${ }^{1}$, \\ Carolaine Gomes dos Reis ${ }^{1}$, Francislaine Suelia dos Santos ${ }^{1}$, Daniela Dantas de Farias Leite ${ }^{1}$, \\ Polyana Barbosa da Silva ${ }^{1}$, Agdylannah Felix Vieira ${ }^{1}$, Raimundo Calixto Martins Rodrigues ${ }^{3}$ \\ \& Magaly Morgana Lopes da Costa ${ }^{4}$ \\ ${ }^{1}$ Federal University of Campina Grande, Campina Grande, Brazil \\ ${ }^{2}$ Jundiai Agricultural School, Federal University of Rio Grande do Norte, Natal, Brazil \\ ${ }^{3}$ State University of Maranhão, São Luís, Brazil \\ ${ }^{4}$ Brazil Teacher of the Paraíba State Network, São Bento, Brazil \\ Correspondence: Mailson Gonçalves Gregório, Federal University of Campina Grande, Campina Grande, PB, \\ Brazil. E-mail: gregoriomailson@gmail.com
}

Received: November 18, 2020

doi:10.5539/jas.v13n2p49
Accepted: December 17, 2020

Online Published: January 15, 2021

\begin{abstract}
The search for nutritious and practical foods during consumption is one of the challenges of the food industry and Greek yogurt with added fruit meets these needs. Therefore, the aim was to prepare Greek yogurt with the addition of different concentrations of carambola jam, as well as to analyze its microbiological quality and its sensory acceptance. Three formulations of Greek type yoghurts were prepared with the addition of different concentrations of star fruit jam F1 (10), F2 (15) and F3 (20)\%, respectively, where they were subjected to microbiological analysis (coliforms at $45{ }^{\circ} \mathrm{C}$, Estaf. coag.positiva (UFC/g) and Salmonella sp.) and sensory analysis, being analyzed the index of sensory acceptance and the intention to buy. The three formulations produced showed excellent microbiological results, that is, all the results obtained are within the standards established by current legislation. With regard to sensory analysis, the formulation F1 (10\%) presented the highest acceptance rate in all sensory attributes, with higher values of $\mathrm{AI}$ above $85 \%$ and with purchase intention close to "certainly would buy the product". Therefore, the yogurts elaborated in this research have the ideal microbiological safety for consumption, without compromising the consumer's health and with excellent sensory acceptance
\end{abstract}

Keywords: acceptance index, food microbiology, dairy products, food safety

\section{Introduction}

Bovine milk in its composition has components that are of great industrial importance, the most valued being protein and fat. Knowledge of the composition of milk is essential for determining quality, as it defines several sensory and industrial properties (Urashima et al., 2012). Fermented milk has technological and commercial prominence, mainly yogurt in its different forms.

Greek yogurt, as well as most yoghurts produced by the industry, is considered as a possible alternative for the consumption of dairy products for people with dietary restrictions, especially lactose intolerance, since during the fermentation process it promotes a 30 to $40 \%$ reduction of lactose present in milk. The final product has a high digestibility rate, besides having several nutrients (Queiroga et al., 2011).

In the food industry, with the purpose of sensorially valuing the product and promoting technological innovations, different ingredients are added, such as fruit pulp, fruits in syrups and/or jams, thereby adding new flavors to the final product and also improving the nutritional value of yogurt (Gonçalves et al., 2018). 
Carambola (Averrhoa carambola) is a culture of Indian origin, but has little technological use, as it contains a high concentration of water content, that is, the referred fruit is considered highly perishable. When ripe, the fruit tastes sweet and slightly acidic, with a golden-yellow color, and has low caloric value, excellent source of potassium and rich in vitamins ( $\mathrm{A}, \mathrm{C}$ and $\mathrm{B}$ complex) and is still mentioned as a possible appetite booster. When cut longitudinally, the star fruit has a star shape, which makes it quite appreciated (Vicente et al., 2014).

Given that the way of feeding the population has undergone frequent changes, the food industry is developing foods that are practical during consumption, but that have excellent nutritional quality and that are free from pathogenic and/or deteriorating microorganisms. Therefore, the present work had as objective, to elaborate Greek type yogurt with addition of different concentrations of the star fruit jam, as well as to analyze its microbiological quality and its sensorial acceptance.

\section{Method}

\subsection{Raw Material and Research Site}

The research was conducted at the Food Chemistry and Biochemistry Laboratory of the Agri-Food Science and Technology Center, Federal University of Campina Grande, Campus Pombal, Paraíba, Brazil. All the ingredients and inputs used in the development of this research were purchased from local businesses in the city of Pombal/PB.

\subsection{Elaboration of the Star Fruit Compote}

The fruits were purchased from local businesses in the city of Pombal, Paraíba, all of them in perfect maturation stage. Initially the fruits went through a selection, in order to eliminate those with any physical changes, afterwards they were subjected to a washing and sanitization process with a sodium hypochlorite solution at 50 ppm for each $1 \mathrm{~L}$ of water. Then, the fruits were cut, presenting a star shape, making the product more attractive, in addition to facilitating the cooking process.

The compote syrup was prepared using $240 \mathrm{~g}$ of sucrose for each $1 \mathrm{~L}$ of water. Afterwards the mixture was heated to a temperature of $80^{\circ} \mathrm{C}$, until a completely homogeneous mixture was obtained. Finally, the cut fruits were added to the sucrose solution at a temperature of $40^{\circ} \mathrm{C}$ and packed in glass jars and hermetically closed.

\subsection{Yogurt Elaboration With Addition of Star Fruit Jam}

The different formulations were made using four liters of whole milk. Initially, the milk was heated to a temperature of $45^{\circ} \mathrm{C}$, after reaching the temperature, refined sugar was added in a pre-established fixed amount as shown in Table 1.

Table 1. List of inputs and formulations of Greek type yogurts with the addition of different concentrations of star fruit jam

\begin{tabular}{llll}
\hline \multirow{2}{*}{ Ingredients } & \multicolumn{3}{c}{ Formulations } \\
\cline { 2 - 4 } & F1 $(10 \%)$ & F2 $(15 \%)$ & F3 $(20 \%)$ \\
\hline Whole milk (L) & 93.95 & 93.95 & 93.95 \\
Refined sugar $(\mathrm{g})$ & 6.00 & 6.00 & 6.00 \\
Milky Culture $(\mathrm{g})$ & 0.05 & 0.05 & 0.05 \\
Carambola jam $(\mathrm{g})$ & 10.00 & 15.00 & 20.00 \\
\hline
\end{tabular}

Then, the mixture of the milk and the refined sugar was cooled to $42^{\circ} \mathrm{C}$, and this temperature is considered ideal to start the process of inoculation of the dairy culture. The fermentation process took place over a period of 9 hours, until the fermented product had an acidity in lactic acid ranging from 0.6 to $2.0 \%$. The entire fermentation process was carried out in a Biochemical Oxygen Demand (BOD) oven at $42{ }^{\circ} \mathrm{C}$. After fermentation, the product was cooled in order to stop fermentation, followed by partial removal of the serum present in the yogurt.

Finally, different concentrations of star fruit jam were added to Greek yogurt, filled in glass jars and stored under refrigeration, at a temperature of $4{ }^{\circ} \mathrm{C}$, for further microbiological and sensory evaluation.

\subsection{Microbiological Analysis}

The samples were submitted to microbiological analyzes of coliform count at $45^{\circ} \mathrm{C}$ (NMP), Estaf.coag.positiva (UFC/g) and Salmonella sp., these being the parameters established by the current legislation (Brasil, 2001). The 
analyzes were carried out according to the methodology described in the Manual of Methods for Microbiological Analysis of Food (Silva et al., 2007) and based on Normative Instruction 62 (Brasil, 2003).

\subsection{Sensory Analysis}

The sensory study of Greek type yoghurt with the addition of different concentrations of star fruit compote, were analyzed by 80 untrained tasters, evaluating the appearance, color, aroma, texture, flavor and overall impression attributes, following the methodology described by Dutcosky (2013).

This research was analyzed and approved by the Research Ethics Committee of the Hospital Alcides Carneiro of the Federal University of Campina Grande-HUAC-UFCG, being registered under the number 33932820.3.0000.5182.

The acceptance test was performed using a hedonic scale with nine points: "9-I liked it extremely", "8-I liked it very much", "7-I liked it moderately", "6-I liked it slightly", "5-indifferent", "4-disliked slightly", "3-disliked moderately", "2-disliked a lot" and "1-disliked extremely". In this research, the acceptance index for each attribute analyzed sensorially was also investigated, according to Equation 1, according to Gularte (2009).

$$
\mathrm{IA}=\mathrm{M} / \mathrm{N} \times 100
$$

Where, $\mathrm{M}=$ average of the sum of the results of the tasters; $\mathrm{N}=$ number of points used in the evaluation scale.

To verify the real intention to purchase the product, a five-point structured scale was used: "5-I would certainly buy the product", "4-possibly buy the product", "3-I have doubts whether or not to buy the product", "2-possibly would not buy the product" and "1-certainly would not buy the product".

\subsection{Statistical Analysis}

The results were expressed with the average values of the tests and the minimum significant difference. The results were submitted to analysis of variance (ANOVA) and the means compared by the Tukey test at 5\% probability. The statistical data were processed using the Assistat 7.7 software (Silva \& Azevedo, 2016).

\section{Results and Discussion}

\subsection{Microbiological Analysis}

The results obtained for the different microbiological analyzes analyzed in the formulations of Greek type yogurt with the addition of star fruit jam are shown in Table 2.

Table 2. Microbiological quality of Greek yogurt with the addition of different concentrations of star fruit jam

\begin{tabular}{llll}
\hline \multirow{2}{*}{ Formulations } & \multicolumn{2}{c}{ Parameters } \\
\cline { 2 - 4 } & Coliforms at $45^{\circ} \mathrm{C}(\mathrm{MPN} / \mathrm{g})$ & Coagulase positive Staphylacocci (UFC/g) & Salmonella sp. \\
\hline F1 $(10 \%)$ & $<0.3$ & $<100$ & Absent \\
F2 $(15 \%)$ & $<0.3$ & $2.3 \times 10^{2}$ & Absent \\
F3 $(20 \%)$ & $<0.3$ & $<100$ & Absent \\
Reference Values (Brazil, 2001) & 10 & $5.0 \times 10^{2}$ & Absent \\
\hline
\end{tabular}

Note. MPN/g: Most Likely Number/gram; UFC: Colony Forming Unit.

For thermotolerant coliforms (coli at $45^{\circ} \mathrm{C}$ ), the results were expressed in Most Probable Number (NMP), in which all samples analyzed are in full compliance established by the current Brazilian legislation (Brasil, 2001). In other words, these results prove that the use of good manufacturing practices contributes in an integral and positive way to this result, since the presence of this group of microorganisms comes from the absence of quality control tools or even cross contamination.

Similar behavior was observed for coagulase positive Staphylococci, with results ranging from $<100$ to $2.3 \times$ $10^{2}$ (UFC/g), and this variation is within the food safety standards established by current legislation, where the maximum allowed for this microorganism is $5.0 \times 10^{2}$ (BRASIL, 2001). Even presenting a higher value in sample F2 for, the result is in full compliance with current legislation, that is, it does not present a risk to the health of consumers.

For Welker et al. (2010) studying microbiological analysis of food, observed that most of the outbreaks of DTAs (Foodborne Diseases) are caused by Coagulase Positive Staphylococci, as it is the second group of 
microorganisms that cause food poisoning. Thus, it is noted the importance of obtaining satisfactory results for this microorganism.

For Salmonella sp., the rules of Resolution RDC $\mathrm{n}^{\mathrm{o}}$ 12, of January 2, 2001/ANVISA establish that for this bacterium the result is absent in $25 \mathrm{~g}$ of food. All formulations developed in this research fully comply with current Brazilian legislation. Therefore, the products do not present possible risks to the consumer's health, considering the absence of this bacterium.

Like the thermotolerant coliforms (coli at $45^{\circ} \mathrm{C}$ ), salmonella sp. is a fecal microorganism. Thus, the absence of quality control tools, throughout the entire production chain, from the handler to all surfaces and equipment used in production, may be the main sources of contamination by this bacterium.

\subsection{Sensory Analysis}

The results obtained from the sensory analysis of Greek type yogurts with the addition of different concentrations of star fruit jam are shown in Table 3. Figure 1 shows the Acceptance Index (AI) for each attribute analyzed in the present study.

Table 3. Sensory acceptance of Greek type yogurts with addition of star fruit jam

\begin{tabular}{lllll}
\hline \multirow{2}{*}{ Attributes } & \multicolumn{4}{c}{ Formulations } \\
\cline { 2 - 5 } & F1 $(10 \%)$ & F2 $(15 \%)$ & F3 $(20 \%)$ \\
\hline Appearance & $7.80 \mathrm{a}$ & $6.71 \mathrm{~b}$ & $6.68 \mathrm{~b}$ & 0.28 \\
Color & $7.96 \mathrm{a}$ & $6.74 \mathrm{~b}$ & $6.80 \mathrm{~b}$ & 0.29 \\
Flavor & $8.06 \mathrm{a}$ & $6.94 \mathrm{~b}$ & $6.97 \mathrm{~b}$ & 0.31 \\
Aroma & $8.06 \mathrm{a}$ & $7.00 \mathrm{~b}$ & $6.94 \mathrm{~b}$ & 0.30 \\
Texture & $8.05 \mathrm{a}$ & $7.01 \mathrm{~b}$ & $7.02 \mathrm{~b}$ & 0.27 \\
Global Impression & $8.07 \mathrm{a}$ & $6.98 \mathrm{~b}$ & $7.07 \mathrm{~b}$ & 0.28 \\
\hline
\end{tabular}

Note. Means followed by the same letter on the line do not differ by Tukey's test, at the $5 \%$ level of significance. DMS: minimum significant difference.

For all the sensory attributes analyzed, it is noted that the formulations developed with the addition of 15 and $20 \%$ of the star fruit compote, did not show statistical difference at the level of $5 \%$ of significance. However, yogurt made with $10 \%$ of the star fruit compote obtained the best averages of the sensory attributes analyzed, differing statistically from the other formulations at the level of $5 \%$ probability. Thus, the different concentrations of carambola jam interfere with the sensory acceptance of Greek yogurt.

For Dutcosky (2013) and Gularte (2009), products that present percentages above $70 \%$ in the AI (Acceptance Index), are classified with an excellent view of acceptance in the consumer market. 

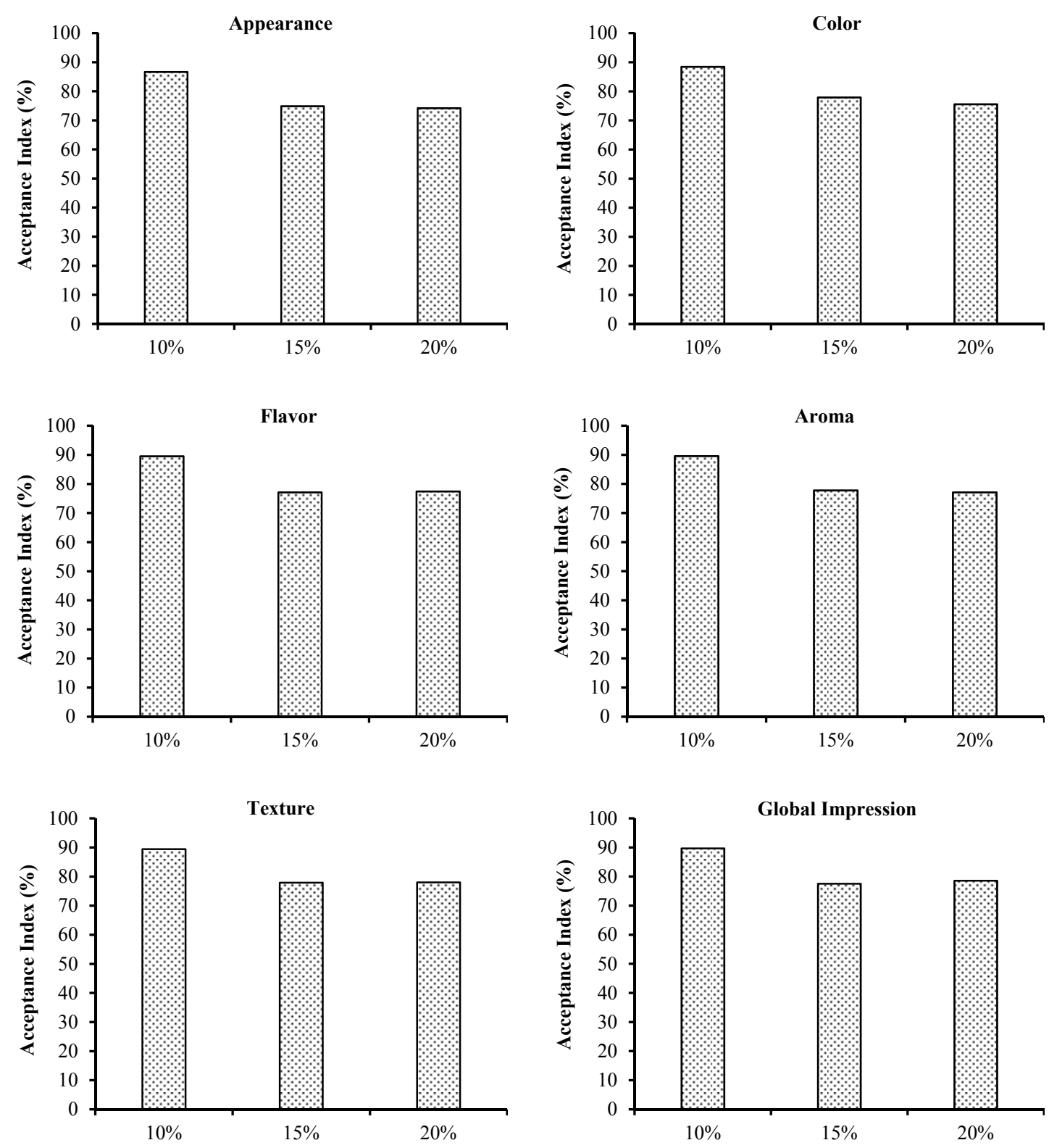

Figure 1. Acceptance index of the sensory attributes of Greek type yogurts with the addition of different concentrations of star fruit jam

Regarding the appearance of the yogurts elaborated in this research, the grades attributed suffered a gradual reduction due to the increase in the concentration of the star fruit compote, that is, the formula $\mathrm{F} 1(10 \%)$ presented a better result and the averages showed variation in hedonic terms "I liked it moderately" and "I liked it slightly". For the color attribute, it obtained a similar behavior, in which the yogurt made with $10 \%$ of the star fruit compote presented the best result, when compared with the other formulations. Thus, both attributes showed percentages above $80 \%$ in the formulation (F1-10\%), while the other formulations presented percentages ranging from 74.22 to $77.88 \%$.

The flavor attribute obtained excellent percentages in relation to AI, with a value above $88 \%$ for the formulation F1 (10\%), this being the best result obtained for the flavor attribute. In relation to the other formulations, they presented percentages above $76 \%$, so it can be said that all formulations have excellent sensory acceptance due to taste, this attribute being one of the most important within the sensory analysis, as it significantly reflects with the intention to purchase any food products. 
For the aroma attribute, the formulation F1 (10\%) showed better sensory acceptance and when compared to the texture attribute, they have similar results for that formulation. The averages obtained for these sensory attributes are classified in the hedonic term of "moderately liked" and "slightly liked", with AI percentages above $85 \%$ for the F1 formulation (10\%), which shows excellent acceptance of the product and for the others formulations presented AI ranging from 77.11 to $77.77 \%$, respectively.

The grades assigned to texture prove that the higher the concentration of star fruit compote in yogurts, the lower the averages for this attribute. The averages in hedonic terms "I liked it a lot" and "I liked it moderately", with percentages of $89.44 \%$ of AI for the formulation F1 (10\%). For the other formulations, the percentages do not present statistical difference between them, since they obtained percentages with a variation of 77.75 and $78.55 \%$.

The texture of food is related to a chemical and physical system that represents a colloidal shape system composed of two non-miscible phases (Oroian et al., 2011). With regard to dairy products, such as yogurt, texture is one of the most important sensory attributes (Rani \& Srividya, 2016). However, traditional yogurts have consistency, creaminess and other texture-related characteristics that are inferior to Greek yogurt (Uduwerella et al., 2018).

The global impression of the three formulations showed averages in hedonic terms "I liked it a lot" and "I liked it moderately" and in relation to the study of AI, formulation F1 (1\%) showed statistical difference when compared to the other formulations elaborated in the present research, with AI above 85\%. Oliveira et al. (2014), analyzing yogurts control and yogurts with different concentrations of taipoca concludes that the gradual increase in concentrations negatively influenced the acceptance of the product

This research also analyzed the product purchase intention, where the results obtained for this sensory parameter of Greek type yogurts can be seen in Table 4.

Table 4. Purchase intention of Greek yogurt formulations with the addition of different concentrations of star fruit jam

\begin{tabular}{ll}
\hline Formulations & Purchase Intent \\
\hline F1 $(10 \%)$ & $4.57 \mathrm{a}$ \\
F2 $(15 \%)$ & $3.10 \mathrm{~b}$ \\
F3 $(20 \%)$ & $2.69 \mathrm{~b}$ \\
\hline DMS & 0.25 \\
\hline
\end{tabular}

Note. Means followed by equal letters do not differ by the tukey test at $5 \%$ probability. DMS: minimum significant difference.

The grades given by the evaluators showed an average variation between "possibly buy the product" to "possibly not buy the product". The highest average of grades was attributed to formulation F1 (10\%) and the lowest average was observed in the formulation developed with the highest concentration of star fruit compote, differing aesthetically from the other formulations at the level of $5 \%$ probability.

\section{Conclusions}

Greek type yogurts with the addition of different concentrations of star fruit compote do not present a risk to consumer health, considering that the results obtained for microbiological analyzes are within the standards established by current legislation. The microbiological behavior achieved in the present research is the result of the implementation of the quality control tools used during the preparation of the products.

With regard to sensory analysis, yogurt made with the lowest concentration of the addition of star fruit F1 (10\%), presented the best results in all the attributes analyzed in the research, as well as the best levels of sensory acceptance, with results above $85 \%$ of AI, which allows us to conclude that this formulation has chances of having an excellent sensory acceptance in the consumer market.

As the food industry changes in relation to the needs of the demands established by consumers, the present research serves as a statistically viable alternative for the development of new food products, in the dairy sector, in the preparation of Greek yoghurts with the addition of fruits in preserves, with functional properties and excellent sensory acceptance. 


\section{References}

Almeida Neta, M. C., Queiroga, A. P. R., Almeida, R. L. J., Soares, A. C., Gonçalves, J. M., Fernandes, S. S., ... Florentino, E. R. (2018). Fermented dessert with whey, ingredients from the peel of jabuticaba (Myrciaria cauliflora) and an indigenous culture of Lactobacillus plantarum: Composition, microbial viability, antioxidant capacity and sensory features. Nutrients, 10(9), 1214. https://doi.org/10.3390/nu10091214

Brasil, Ministério da Agricultura, Pecuária e Abastecimento. (2003). Instrução Normativa $n^{\circ}$ 62, de 26 de agosto de 2003. Oficializa os Métodos Analíticos Oficiais para Análises Microbiológicas para Controle de Produtos de Origem Animal e Água. Diário Oficial da União (DOU), Brasília, DF.

Brasil, Ministério da Saúde, Agência Nacional de Vigilância Sanitária. (2001). Resolução-RDC n $n^{\circ}$, de 02 de janeiro de 2001. Regulamento técnico sobre padrões microbiológicos para alimentos. Diário Oficial [da] República Federativa do Brasil, Brasília, DF.

Dutcosky, S. D. (2013). Análise sensorial de alimentos (4th ed., p. 531). Curitiba: Champagnat.

Gonçalves, N. M., Ferreira, I. M., Silva, A. M. O., \& Carvalho, M. G. (2018). Iogurte com geleia de cajá (Spondias mombin L.) adicionado de probióticos: Avaliação microbiológica e aceitação sensorial. Revista Brasileira de Higiene e Sanidade Animal, 12(1), 54-63. https://doi.org/10.5935/1981-2965.20180016

Gularte, M. A. (2009). Manual de análise sensorial de alimentos (1st ed., p. 66). Pelotas: Editora Universitária da Universidade Federal de Pelotas.

Oliveira, E. N. A., Santos, D. C., Figueirêdo, R. M. F., \& Feitosa, R. M. (2014). Development and characterization of yogurts produced with tapioca. Journal of Biotechnology and Biodiversity, 5(2), 110-120.

Oroian, M. A., Escriche, I., \& Gutt, G. (2011). Propriedades reológicas, texturais, de cor e físico-químicas de alguns produtos de iogurte do mercado espanhol. Food and Environment Safety Journal, 10(2), 24-29.

Queiroga, R. C. R. E., Sousa, Y. R. F., Silva, M. G. F., Oliveira, M. E. G., Sousa, H. M. H., \& Oliveira, C. E. V. (2011). Elaboração de iogurte com leite caprino e geleia de frutas tropicais. Revista do Instituto Adolfo Lutz, 70(4), 489-496.

Rani, K. S., \& Srividya, N. (2016). Efeito da inulina, frutooligossacarídeos e L. acidophilus na formulação de um iogurte simbiótico. Jornal Asiático de Pesquisa sobre Laticínios e Alimentos, 35(1), 37-40.

Silva, F. A. S., \& Azevedo, C. A. V. (2016). The Assistat Software Version 7.7 and its use in the analysis of experimental data. African Journal Agricultural Research, 11(1), 3733-3740. https://oi.org/10.5897/ AJAR2016.11522

Silva, N., Junqueira, V. C. A., Silveira, N. F. A., Taniwaki, M. H., Gomes, R. A. R., \& Okazaki, M. M. (2007). Manual de análises microbiológicas de alimentos (3rd ed., p. 535). São Paulo: Logomarca Varela.

Uduwerella, G., Chandrapala, J., \& Vasiljevic, T. (2018). Pre-concentration of the yogurt base by ultrafiltration to reduce the generation of acid whey during the manufacture of Greek yogur. International Journal of Dairy Technology, 71(1), 71-80. https://doi.org/10.1111/1471-0307.12393

Urashima, T., Fukuda, K., \& Messer, M. (2012). Evolution of milk oligosaccharides and lactose: A hypothesis. Animal, 6(3), 369-374. https://doi.org/10.1017/S1751731111001248

Vicente, J., Nascimento, K. D. O., Saldanha, T., Barbosa, M. I. M. J., \& Júnior, J. L. B. (2014). Composição química, aspectos microbiológicos e nutricionais de geléias de carambola e de hibisco orgânicas. Revista Verde de Agroecologia e Desenvolvimento Sustentável, 9(3), 137-143.

Welker, C. A. D., Both, J. M. C., Longaray, S. M., Haas, S., Soeiro, M. L. T., \& Ramos, R. C. (2010). Análise microbiologia dos alimentos envolvidos em surtos de doenças transmitidas por alimentos (DTA) ocorridos do estado do Rio Grande do Sul, Brasil. Revista Brasileira de Biociências, 8(1), 44-48.

\section{Copyrights}

Copyright for this article is retained by the author(s), with first publication rights granted to the journal.

This is an open-access article distributed under the terms and conditions of the Creative Commons Attribution license (http://creativecommons.org/licenses/by/4.0/). 